ESJ Humanities

\title{
The Dead Brother's Ballad as a Balkan Shared Place of Memory
}

\author{
Katica Kulavkova, PhD
}

Literary Theory and Hermeneutics, Comparative Literature

Macedonian Academy of Sciences and Arts, Macedonia

Doi:10.19044/esj.2021.v17n39p1

Submitted: 12 October 2021

Accepted: 04 November 2021

Published: 30 November 2021
Copyright 2021 Author(s)

Under Creative Commons BY-NC-ND

4.0 OPEN ACCESS

Cite As:

Kulavkova K. (2021). The Dead Brother's Ballad as a Balkan Shared Place of Memory. European Scientific Journal, ESJ, 17 (39), 1.

https://doi.org/10.19044/esj.2021.v17n39p1

\section{Abstract}

There is a ballad saved in the folklore and oral literary tradition of several Balkan peoples and their collective memory under different names, but with the same proto narrative: "The Dead Brother's Song" (Greek), "The Return of the Dead Brother" (Macedonian), "Brother and Sister" (Serbian, Montenegrin, Bosnian), "Lazar and Petkana" (Bulgarian), "Constantin and Doruntinë" (Albanian), and "Voika" (Romanian). Appearing in several linguistic and stylistic variants, this ballad can be considered as an illustrative shared place of collective Balkan memory. Saved both as a local (national), and regional (transnational) cultural heritage, The Dead Brother's Ballad contains the most significant aspects of the Balkan cultural paradigm: mythical, mystical, folkloric, religious, ethical, and historical ones. The interpretation of this ballad in the mythopoetic context demystifies the Balkan identity prejudices and the misinterpretation of the shared cultural heritage. Methodologically, the present interpretation of the Balkan ballad is syncretic, combining diverse theoretical and interpretative tools from mythology, theory of literature, culturology and post-postcolonial criticism. Instead of giving an ultimate conclusion, this paper deconstructs the dominant interpretative strategies of the Balkan spiritual and historical heritage in the last two centuries (adoptive, contestable, convertible, competitive) showing that they all actualise the conservative principles of cultural hegemony on the Balkans. Having a scientific consensus for the transnational aspects of the Balkan cultural heritage might be a starting point for a new, empathetic strategy of 
their perception.

Keywords: Shared place of memory, "The Dead Brother's Ballad", Balkan cultural paradigm, mystical structures of imagination, mythopoetics, transmigration

\section{Introduction}

\section{Prologue}

The Anthology of Balkan Poetry, initiated by the Greek publicist and editor of the Anti magazine in Athens, Christos Papucakis (1934-2009), was edited by several national editorial offices, translated into several Balkan languages and published in several countries. Instead of a motto, the anthology contains different local versions of The Dead Brother's Ballad in the following languages: Albanian, Bosnian, Bulgarian, Greek, Romanian, Serbian and Macedonian. ${ }^{1}$ The preface to the anthology states:

"there have always been many common elements rooted from the early ages (common linguistic influences and depth of memory, similarities of different kinds, contacts and intertwining of myths and legends, customs, music, songs, costumes, cuisine) although, of course, differences are visible just the same. The awareness of these common elements resulted, even in the time of the Ottoman Empire, in attempts of reuniting the Balkan community, first of which is that of Rigas Feraios. ${ }^{2}$ The current attitude accepts the inevitability of the formation of large communities by simultaneously retaining the specific characteristics of nations and minorities. The essence lies in maintaining the polymorphness by developing the common/binding elements, the elements that guarantee the peace and ensure the distinctness." (Papucakis et al, 2008:16)

The ballad about the dead brother is one of those creations that present the regional Balkan cultural prototype as the actualisation of the mythical memory and of the anthropological structures of the imaginary. ${ }^{3}$ It has been passed on in the historical time-space of the Balkans in numerous stylistic and dialectic variants, marked by archaic and improvising features, as is common for the oral tradition. It contains a common story of the resurrection and

\footnotetext{
${ }^{1}$ Walter Puchner $(2016$, 68) cites multiple sources of the Balkan variants of the ballad (including the Hungarian one).

${ }^{2}$ Rigas Feraios or Velestinlis $(1757-1798)$ is a Greek writer.

${ }^{3}$ Researches of folklore point to the relatedness of the ancient Greek myths of Demeter and Persephone, Adonis and The Dead Brother's Ballad (Puchner 2016).
} 
transmigration of the dead brother in order to fulfil his given word. This ballad has been archived as part of the folklore of the Balkan people under different titles and version, yet containing the same story: "Constantin and Doruntinë" (Albanian), "Lazar and Petkana" (Bulgarian) ${ }^{4}$, "The Dead Brother's Song" (Greek), "Mrtov brat na povratki" ["The Return of the Dead Brother"] (Macedonian), "Brother and Sister" (Serbian, Montenegrin, Bosnian), "Voika" (Romanian). The name of the sister varies: Evdokia/Ivdokja, Evdokia/dzan Fekia, Petkana, Yelitsa, Areta, Voika, Doruntine, whereas the brother's name has only the following variants: Konstantin/Kostadin, Lazar and Yovan. The place where the sister marries also differs, as well as the description and the notion of remoteness and foreignness: sometimes it is a village across three mountains or a city across the sea, or Babylon, and sometimes it is Constantinople.

The Dead Brother's Ballad is more than just different linguistic and stylistic versions, as it presents a palimpsest of multiple cultural and religious matrices: orphic, magical, ritualistic, mythical, religious, folkloric and historic. This is due to the sacred being a trans-religious and trans-cultural good and, hence, this ballad is an illustrative example of a shared place of the Balkan folkloric, mythical, mystical and religious heritage. Far from being the sole shared place of memory of the Balkan immaterial cultural heritage, this ballad is, nonetheless, a very good illustration of the cultural substrate of the memory of the Balkan people (Peeva, 2003).

Apart from being a poetic reflection of the initial mythical understanding of the world, this ballad also points to the mystical constants in the Balkan worldview. The mythical image, deeply embedded in the collective unconscious, possesses a latent power to invoke similar situations in the historical reality. It indicates that unconscious contents of the mythical images in the folk tradition need to be subjected to combined (syncretic) interpretative strategies. The correct understanding of the collective memory, including the forgotten unconscious contents as well, is one of the ways they become influential historical factors. In fact, folklore remains in dialogue with reality even when it is mystifying.

\section{The Macedonian Version of the Ballad}

The ballad is, by definition, a synchresis of dramatic, lyrical and epic elements. The Macedonian versions of The Dead Brother's Ballad contain a substantial amount of narration, giving the impression that the ballad was originally given in the form of a story inspired by a dramatic event. It is a matter of a genre transformation: the dramatization and poetization of the

${ }^{4}$ As early as 1896, prof. Ivan Shishmanov wrote a study entitled "The Poem of the Dead Brother in the Poetry of the Balkan People" (SANU) and in it, he classifies this poem as a ballad. 
archaic mythical story, which in the oral tradition comes as a result of the different performances of the poem. The performance being theatrical and oral narration being rhythmical, they have the tendency to turn into poetry in time. Genre transformation is most visible in the hybrid genres, through the frequent and indicative presence of clichéd epithets (white castle, white room), numerical symbols (three, nine) and the mixing of the Christian with the Pagan beliefs (mystical images of the world, superstition).

Cited here will be a fragment of one of the two Macedonian versions of this ballad, published in the second volume of Makedonski narodni umotvorbi [Macedonian Popular Literature] by Stefan Verkovic (1985, 205207), published under the title "Mrtov brat na povratki" ["The Return of the Dead Brother"]. The second version is "Mrtov brat ja vodi sestra si na povratki" ["The Dead Brother and His Sister Return"]. The cited first version is shorter than the second one, which has the structure of an epic and contains almost 300 verses.

\section{The Return of the Dead Brother}

A dreadful disease came

True plague of the plagues

Mowing down young and old

And Kostadin as well.

His mother left alone

In their vast house.

She goes in and out

And curses Kostadin:

May you be cursed, Kostadin

For giving away my Evdokia

Far, far away,

As far as Constantinople

God said unto the angel:

Go down on Earth

Dig out his grave

Turn his coffin

Into a fierce and fast horse

So he can go and get his sister

And bring her to his mother.

The angel of God came forth

And gave Kostadin a soul

On Easter, the second day.

He brought his sister to the middle of the village 
And said:

You go on your own, Evdokia,

For I must return.

Evdokiya went on her own

To their heavy gates

And shouted to be heard.

Her mother came

To open the heavy gates.

When she saw Evdokia,

She started crying,

And as soon as they both embraced,

They turned into marble.

\section{The Interpretation of the Ballad in the Context of a Balkan Mythical Memory \\ 3.1. Mythical and folkloric structures in the ballad}

The Dead Brother's Ballad is inspired by a narrative in the folklore of multiple Balkan people that actualises the archetype of "the living dead". The youngest of nine brothers (Lazar, Konstantin) is predestined to play the ritual role of the culprit, victim, hero and saviour. This accepted cliché of values has more of a symbolic purpose rather than any real meaning. It is only very rarely, as in the Romanian version, that the story deviates from the cliché and the role of the resurrected brother-saviour is given to the oldest brother.

What role does the dead brother have? He rises from the dead in order to fulfil two functions: the first is a practical aim to protect his mother and return his sister from a foreign land (Istanbul) home, to maintain the family health and, second, due to the mystical need to obtain his soul's peace after death, to free himself of his mother's anathema and fulfil the given promise to her. The ballad presents a mystical feat and a rite of moral catharsis. However, this mystical feat ends dramatically because, when they meet again, the mother and the daughter petrify in their final embrace and the brother returns to the world of the dead, where he rightly belongs. The petrification (into marble, characteristic for the Macedonian region) of the mother and the daughter can be read as a parable of the unity of the family and a symbol of the devotion to the motherland. In the ballad itself, this embrace is the culminating point of the dramatic situation.

The ballad also evokes the fatality of the moral hierarchy based on a complex of religious, mystical and pragmatic motifs. Despite technological progress, there is a belief that persists on the Balkans according to which death does not take those who have wronged against divine justice or have perpetrated some form of treason against divine ideals that, as a rule of thumb, 
are collective and universal. The dead brother performs the ritual of appeasing divine justice in order to achieve a personal and familial liberation from the anathema, thus enabling the renewal of the family tradition. The anathema itself is a parable of the mystical collective heritage and pagan superstition.

The Dead Brother's Ballad contains numerous motifs with multiple functions: first of all, they build an aesthetic whole of signs and meanings that reflect the primordial structures of the Balkan family; second, the poem itself is a performing of the ritual of word/promise giving, resurrection and promise fulfilment; third, the poem is a dramatization of the fatal loyalty to the family (genesis, tradition) and the word that has performative power - to promise, to curse, to liberate, to purify, to appease. The language itself is spiritual heritage therefore containing not only the existential but also the magical, mythical and religious experiences.

The spiritual archetype of the resurrected brother is identical in the general Balkan spiritual heritage and is only different in its language, narrative, versification, rhythm, style and visuals. In the Bulgarian version of the "Dead Brother" the name of the brother is Lazar and he rises from the dead, therefore making the poem explicitly Christian (even though it has a mystical undertone) and opening the possibility to read it as an actualisation of the resurrection archetype (Lazarus week is celebrated in honour of Lazarus of Bethany whom Jesus helped resurrect on the fourth day of his death - a miracle that helped many to believe in Christ, according to John 11: 1-45). Lazar's name comes from Eleazar - 'he whom God helped resurrect'

In all versions of this poem, not only the Bulgarian, great attention is given to the description of the resurrected Lazarus (smell of earth and mould, darkened pale face, whenever he approaches the threshold of his mother's home he must go back to the world of the dead, he must not appear dead before his mother). The driving force behind the resurrection in The Dead Brother's Ballad is the keeping of his given word, and the resurrection itself is supported by God, which is explicitly mentioned in all the versions of the ballad (God, being merciful, sends two angels to help Lazar rise). In one Macedonian version there is mention of the resurrection as "divine miracle", when "the earth opened", on the second day of Easter, the great Christian holiday of the Resurrection, further proof of the theory of a more recent, Christian interpretation of the archetype of the "living dead".

The poem culminates tragically with the petrification of the mother and the daughter out of excitement in a last embrace (this resembles the idiom "dying of laughter"). This very image of petrification is the invariable element of the poem and a shared image of the Balkan family, an image of a family that is completely torn (living abroad, exiled, as janissaries, as migrant workers). First, the plague devastates the family (nine brothers with their families) and then the mother and daughter die of love that has become fear of 
another separation. Fear is powerful. Together, even in death. The Macedonian oral literature has examples of the petrification of entire families as well.

Herein, in this dramatic situation, the magic power of the word is evoked - the power of the word that curses and the power of the given word (besa). It is supposed that the mother's curse is effective, that the curse is eventually fulfilled. This is due to the fact that a curse is - as Bunson says - "a verbal invocation or appeal for an injury, evil, or death to befall a person, place, or thing... curses are considered one of the main ways by which people become revenants" (Bunson, 1993, 57-58).

The same is implied by the symbolism of the given word - the belief that the promise must be kept, otherwise there would be no peace even after death. The harmonization between word and reality is the condition necessary for the individuation of the individual and for the integration of the family and the community. Words should not be spoken in vain, in the form of empty promises and anathemas, for they have a performative and persuasive power to turn into deeds. Speaking in vain is not harmless, nor is it without consequences. An example of this is the rhetoric of politics which, by definition, is based on speaking in vain and giving empty promises, or utopian representations of the future, and is a latent source of misconceptions and danger (Aristotle, 2002).

\subsection{The Curse and the Living Dead as Narathemes in the Ballad}

"The Dead Brother's Ballad" is a poem about the fatal power of the word turning into a deed, action and reality. According to the mythical consciousness, but also the theory of speech acts (Searle 2003), the word has the power to bless and curse, to heal and sicken, to unite and separate, to build and destroy, to bring to life and kill. This poem is a warning that spirituality is immune neither to language nor to the moral embedded in it, in the linguistic forms as the given word. It is a warning that we must be careful with language, because by neglecting it, we neglect our spirituality, as the soul, the word and awareness of good and evil (in a moral and religious sense) are not too far apart. Many fixed phrases that function as fixed metaphors and phraseologies: "the living dead", "given word", "divine justice", are powerful narathemes, stories in their inception, which gain significance at the end of an event (drama, a family tragedy) or at the beginning of a following event.

The youngest of nine brothers has committed a sin by convincing his mother (and his brothers) to marry her daughter Evdokia off to a stranger (across a mountain, across the sea, in Constantinople/Istanbul, in Babylon) and promising he will bring his sister home to visit her mother often. After the "plague" has devastated the family (destroyed home, epidemic), taking the lives of all nine brothers (in some versions, their wives and children as well) and leaving the mother all alone in an empty house, she, the Mother, in an 
outburst of atavistic pain, curses her son for not keeping his word and breaking his promise or oath. In the system of traditional moral values, this is treason and therefore an unforgivable sin.

The semantics of the word curse in Macedonian (kletva) is close in meaning to the word 'promise/swear' (zakletva): the son has sworn he would take his sister home to visit her mother, and the mother curses him for not keeping that promise or oath. In the first case, we curse ourselves by giving our word, and in the second, we are cursed by someone else for not having kept our word or fulfilled our promise, which we have sworn to do (swear and curse are morphologically identical in Macedonian). Thus, the subject becomes the object of a curse, and the person is punished, a victim of a curse. In such circumstances, the person must perform a rite of self-sacrifice in order to be forgiven. The dead brother symbolically rises from the dead thus becoming human again, fulfills the promise and goes back to the world of the dead, this time, however, spiritually integrated with himself.

In the version collected in the third volume of Verković's anthology $(1985,61)$, much richer in mythical images and lyrical descriptions, this is the mother's curse: "May you find no peace, son / for sending my daughter / across three mountains". This version of the poem "The Dead Brother and His Sister Return" is one of the most impressive ones, filled with drama and rich in primordial symbolism - the angels, with the help of three serpents, wake Kostadin from the dead; while riding home, the sister Evdokia/Dzan Fekia hears the sound of two nightingales wondering how it is possible for "the dead and the living to ride together"; the sister smells the scent of earth on her brother's palms, the family vineyards are desolated, as well as the cemetery... All this takes the form of a dialogue between the brother and the sister, by giving form to the idea of transmigration suggested in the very title of the poem (the return). What follows is a description of the episode of the lost golden ring, a sign of recognition, and then a mythopoetic description of the salvation of Kostadin, who finally returns to the world of the dead as the earth receives him, purified from the anathema.

The curse is the occult reason why the son cannot rest in peace. His soul is somewhere halfway, he is neither living nor dead; the earth rejects him, the oil candles do not burn in his memory. Only God (divine justice) can show mercy on him and help him, and that is achievable only with the help of miracles - he would resurrect only for a short while, return to the place of sin, and fulfil his promise in order to satisfy justice and appease his soul. That would close the circle between the given word, the mother's curse, the resurrection, the divine justice, the penance of the sin and, finally, resting in peace. Symbolically, this allows for the performance of individuation to be performed, if we think of it as harmonization and empathy between man's 
many personifications, rather than a formal union of the separate, conflictive parts of our being.

Partly poetic, partly biblical, the miracle of resurrection is evoked in the image of the ground that opens. A dramatic metamorphosis takes place at that moment, of death into life, so that the brother can ride the horse to his sister's house and take her to the threshold of their mother's house. The brother then returns to the grave while in the family house, there is a moment of anagnorisis between the mother and daughter, and the brother's ring (in some versions it is the sister's ring) serves as proof that the miracle of resurrection had indeed taken place.

In the Macedonian versions of the same ballad two mythical images are emphasized: the first presents the motif of the dead brother as an antithesis, as an actualisation of the 'living dead' archetype: "the dead and the living talking", "the dead rises"; whereas the second image is an antinomy of the "last encounter", when the mother and the sister were "alive when they embraced / dead when they separated" (Penušliski, 1983, pp. 202-203). While the first image is crucial for the main story, the second is the final image that marks, ultimately, the culmination of the shadow of the curse: a dramatic finale of the death of the family, the powerlessness of the people in the face of epidemic (the plague/cholera), as well as the unstoppable force of primordial urges. Despite these difficulties, however, the ballad is perfect proof that the moral feat has been accomplished, in an extraordinary effort from beyond life and death. The carrying out of divine justice is irreversible.

The ballad also presents two fatal dramatic situations the family faces: the sickness to death (due to the epidemic) and love to death (to be together even in death). In the south Slavic languages, there is the expression to die of laughter which stands for joy to death! Misfortune never comes alone but, as the maxim goes, it is followed by a series of other misfortunes. The same is true for justice, which does not come in vain either. This is one of the implicit morals of this ballad: people need to be careful and considerate with their words, have empathy towards each other and be ready to perform any deed! The deed is synonymous of a miracle and bestows meaning to our existence. There are interesting examples of this in the Macedonian oral poetry, let us only mention the poems about Bolen Dojchin (sick Dojchin) and the Black Arab here (Kulavkova, 2009).

\subsection{Word as a Balkan Folk Narratheme}

Folk culture, especially oral literature, rituals, customs and moral norms of the Balkan people are specific, yet with many common elements. As a result, they retain their own identity but all together form a system of signs of culture with a more general, supra-ethnic character. In the process of universalisation of the separate cultural systems, inspired by the intercultural 
communication through the centuries, a paradigm of the Balkan cultural and linguistic alliance was formed. This paradigm is based on some of the shared places of mythical, historical and folkloric memory. These shared places of collective memory are not always recognised as Balkan or universal, but more often as independent, local and ethnic. Nonetheless, the retained immaterial cultural heritage bears witness to the presence of such shared places of memory with most of the nations on the Balkans. In this essay, the focus is on the oral literary heritage in which the mythical and the historical consciousness are intertwined, as are the archaic and Christian moral codices, due to the fact that those points of intersection are the very reflection of the dominant 'Balkan worldview' (Kulavkova, 2007).

To illustrate this, we are going to present the category of besa (given word, promise, vow, oath). It is usually presupposed that this category is exclusive for the mentality and culture of the Albanians. However, numerous examples show that this category is characteristic of most Balkan peoples. The different versions of the Dead Brother's Ballad contain memory traces of the effectiveness of the 'given word' in multiple Balkan traditions. The synonyms of the word besa in the Macedonian language are, for example, a reflection of the importance of the moral law of the oath and the punishments that follow for anyone who disregards it. The breaking of an oath is a type of metaphysical evil subject to mystical punishment.

The paradigm of the ultimate sin, embodied in the tradition of the unfulfilled promise is a common Balkan and human heritage in the realm of natural law and unwritten prohibitions. The culture of the given word belongs to all peoples that have kept its paradigm in their mythical consciousness and transformed it into a contemporary moral codex. Through the prism of the 'given word' the different intersubjective profane and religious experiences can be observed: between two individuals, in the family relations and even in the relations among ethnical and political communities (coalitions or synchresis). Whenever the given word is broken between individuals or between families, it incites a series of dramatic, even tragic consequences: a guilty conscience, sense of sin, anger, and a desire for revenge (punishment, murder, conflict, war) to horrific cursing of the person who has broken the oath, thus creating mystical situations in which a human being is put in the position of the representative of divine justice. Whenever the given word is broken, the balance in people's relations is disrupted. The once disrupted balance between the given word and reality is hard to restore. It creates situations of sin whose protagonists are those who have sinned and those who have been sinned against (betrayal, trauma). In order to avoid the imminent punishment and appease the divine power, people perform specific actions in order to compensate for the broken promise and gain forgiveness. 
The mythical consciousness is open to all forms of compensation from the sin committed by breaking a given word, including miracles, as is, for example, the resurrection of Lazarus with divine help (Jesus Christ). The mythical compensation minimises the differences between the profane human and the sacred divine instance, but gives the profane world power reserved for God. Such power is the resurrection of the dead, the symbolic transformation of death into life. In the name of the cult of oath giving, mythical consciousness raises the dead and gives them an opportunity to repent for their sin and fulfil the given promise. This has created the mystical vision of the living dead. The oxymoronic reception between life and death aims to appease the spirits (rage, vengeance, punishment) and restore the necessary harmony. It is solved in an animistic manner by the dead sending their souls to do what they had not done during their life. The soul knows no death. However, in order for it to travel somewhere, a magical rite of invocation of the soul is needed, as well as a superhuman desire for justice, forgiveness and peace.

Some Balkan people have created a cult of the given word, whereas others degrade it in the system of the current moral goods. This revision of the moral values speaks volumes about the ruling moral code and not so much about the genesis of the code. In other words, the current cultural heritage is not exhausted by its historical genesis and can not be rightfully interpreted only through the prism of the exclusive ethnocultural uniqueness, autochthony and domicile. Depending on how they are interpreted, the shared places of mythical and historical memory have a dual function: integrative and disintegrative. The cultural history of the Balkans bears witness to both of these functions and both are active at all times. They serve as proof of the historical, cultural and anthropological similarities of the neighbouring Balkan people.

\subsection{The Mythopoetic Memory and the Identity}

The Dead Brother's Ballad contains a double paradigm: on the one hand, there is the projection of Balkan theatricality, and on the other, the witnessing of the (universal) effectiveness of the word. The irrational belief in the power of the living Word, be it a blessing or a curse, grows into actual power. There are numerous examples of this in folklore: the word turns into a deed, the prophecy comes true, the curse is effective, the given word must be kept, even after death. The religious norms are moral norms of the highest order and they contain traces of the animistic and other pagan beliefs. The dramatic entrapment of the Balkan consciousness in the traps of negative stereotypes and prejudice against oneself and the other, leads, almost without exception, towards miracles and divine forces (Deus ex machine). We must, however, note that the linguistic memory serves as a reminder that the Balkan peoples see Good as inseparable from the idea of the Beautiful, and Evil is 
understood as the other face of the Ugly (sinful, incongruous, grotesque), thus correlating aesthetic virtues with ethical values.

The Balkan circulus vitiosus contains the collective unconscious, the irrational, the cult and the occult. Because of this mental baggage, there must be real forgiveness between individuals and communities close in space, language, myth and history. If we are to form an image of the Balkan family based on "The Dead Brother's Ballad", its structure is marked by the figure of the Mother, i.e. the female, the lunar, the nocturnal, pre-Christian principle. While the image of the Father is absent from the poem, the figure of the "single Mother" is omnipresent. None of the variants contains verbal or narrative traces of the father but merely a mention of "father's gates". This configuration of the family missing the solar principle, or the patriarchal hierarchy and pragmatisms, while being dominated by the law of passion, almost exclusively leads to an unhappy climax and a tragic denouement of the dramatic situation. The family tragedy is a parable of the Balkans. The symbolic dominance of the Mother is suggestive of the ancient origin of the plutonian motif of death and resurrection.

The Dead Brother's Ballad has managed to preserve certain memories of the matriarchal matrix of consciousness and the mythopoetic memory of the Mother's uncompromising love as well as the family and community cult, and it suggests that perhaps the surplus of pathos is an anthropological constant of the Balkans that becomes actualised in certain historical circumstances and causes dramatic situations. Atavism sometimes takes centre stage in the historical scene, other times it stays at the margins, yet it always seems to be present, even if only latently. The Balkan female principle of killer love is a reflection of the worldview marked by extreme prejudice that produces conflicting relations, firstly inside the family (the people) and then outside of it, in the wider community of the Balkan nations. Identities become 'killer identities' in the Balkans but in other regions in the world as well, if they are not accepted in their complexity ("My identity, my allegiances", as Maalouf said, 2003, p. 6).

This situation poses the question of the appeasement of the two principles, the lunar and the solar, and one should look no further than the consciousness of the shared places of memory as a condition without which the harmonization of the relations between neighboring and very often related peoples seems unattainable. The culture of forgiveness and the collective catharsis from the inherited identity complexes could create a new sacrality, a new regional codex of harmony in the here-and-now.

\subsection{The Metempsychosis Motif and its Universality}

The dead brother topos in the ballad is folkorised and Balkanised, even though it has a universal philosophical dimension and its origin is mythical. 
The motif of resurrection is an archetype that is actualised in the traditions of many nations from different parts of the world and in different eras. I will cite an example from Japanese and Chinese popular literary traditions covering the motif of metempsychosis, in accordance with Buddhist philosophy. It is the short story "A Meeting on Chrysanthemum Day by Ueda Akinari (17341809), a Japanese writer from the $18^{\text {th }}$ century, inspired by an ancient Chinese story from the Ming Ku Kin Siao Chuo epoch (between the 14 and 17 centuries) entitled "A meeting between a dead and alive friend at the party in honour of Fan Kui-k'Ing". The Chinese story is about the friendship between the writer Chang Chao and his brother Fan. Prevented from coming to his brother on time, on Chrysanthemum Day, to keep a given promise, Fan sacrifices himself by suicide because he believed that only by being dead, he can send his soul to the brother's party, instead of himself (Akinari 1966: 8293). The self-sacrifice is the introduction to the deed and the occult experience is a component of the real human life, a way to survive in the world of reality (Petrić, 1966, 21-27). In Akinari's Japanese story the narrative ambient is actualised in a Japanese manner, in which the dramatic situation takes place between the warrior Akana and his benefactor Samon, and a central place is given to the motif of vengeance and punishment of the guilty ones. In both stories, the Chinese and the Japanese, however, the main point focuses on loyalty, understood as a synonym for honour and justice.

The mythical image of the transmigration of the soul is ancient and universal. The belief in the power of the soul to travel, to be independent from the body, is common for the people of the Far East, ancient Egyptians, Thracians, Hellenes, Latins, Slavs, Nordic people (Haraldsson 2006) as well as all indigenous populations. It is believed that it was conceptualized in the context of the orphic religion, since Orpheus (circa $6^{\text {th }}$ century BC), namely on the Balkans (Greece, Bulgaria, Macedonia). It has the status of a philosophical and theosophical topos. Plato wrote about it in the last part of his Republic (Plato, 2004, 320-326) when writing about the myth of Er, the son of Armenios. The myth of the transmigration of the soul is also an important literary topos (Horace, Vergil, Dante, Melville, Joyce, Nietzsche, Poe, Blavatsky). In this context, metempsychosis is related to the terms resurrection and reincarnation, transmigration and palingenesis, as well as the religious and ethical principle of sin and curse purging, or the dramatic principle of the cathartic release of the surplus of passions that is the root of all tragedy. Based on the sublime urge of fidelity, the transmigration of the soul has a dual meaning: on the one hand, it humanizes and on the other, it sacralizes the image of the human. 


\section{The Mystical Structures of the Imaginary}

The psychological, moral and linguistic factors are inseparable in the bestowing and ridding human existence of meaning. The consequences of the disturbed harmony between the psyche, the moral and the language are dramatic. There is, in fact, a substrate of virtuous psycho-moral patterns inscribed in the cultural heritage of humankind that are read as "mystical structures of the imaginary" (Durand, 1969, 307-320). The semantic knots of The Dead Brother's Ballad can help us draw some general conclusions about the anthropological particularities of the Balkan people on the Balkans (geopsychology, applicable to the contemporary social circumstances as well). For example, the mythical image of the petrification of living humans is semantically entropic and can only be explained if the pre-verbal, imaginative way of thinking is accepted, through an emotional and mental visualization. It is a matter of an almost magical transformation of mythopoetic implications.

Together with the very characteristic enjoyment of life, the Balkan people seem to have an almost mystical affinity to be together in death. Due to the diasporic way of life on the Balkans, the systematic breaking down of the family (migrations, exile, janissary, religious and ethnic conversions, population exchanges), the frequent abductions of children, young men and women, the smaller Balkan people have traumatic memories reflected in the collective memory and psychology in the form of a fear of the final separation and oblivion.

The Balkan folk poetry contains elements of an archaic mysticism, a mythical narrative and rituality. The Dead Brother's Ballad also reflects the tendency to mix the sacred and the profane, the mythical and the historical. The thematic layers of the poem reflect the matriarchal dimension of the Balkan family code. The Dead Brother's Ballad is also a ballad of the absent father and the present mother. The fatal role of the mother is the antipode to the epic stereotype of the male heroism. The ballad warns that the image of the Balkans should not be simplified, while including in its structure the epic and the lyric principle, both glorious in their superhuman dimension.

Due to its mobility and fluidity, the immaterial cultural heritage knows no strict state, national or religious borders. Each ethnocultural and religious community may, in certain social and historical conditions, recognise a universal spiritual heritage as its own spiritual good. This act of recognising the belonging of a cultural good as one's own shows the value of perception and interpretation of the cultural and historical heritages. It moves in two directions: from local to universal, and from universal to local. Despite, or because of this immanent mobility of the spiritual cultural goods in the area of the oral tradition, myth, ritual, symbols, literature, music and language, they are susceptible to adoptive and exclusive interpretations. 
When such interpretations are adopted in the form of someone's national interest, the universal and the regional cultural goods in particular, begin to be seen as local and autochthonous values. This appropriation of the supra-national cultural goods as national ones usually radicalises the interpretative strategies in the direction of national exclusivism and the denial of the right of other nations to nurture the inherited cultural goods as part of their collective memory and cultural history. This may sometimes lead to comic situations and other times to conflicting misinterpretations.

The autochthony of the spiritual goods is difficult to document through the historical intercultural and inter-ethnic transfer in space and time. The more one enters the ancient past, the more the spiritual goods show their universal dimension. Based on these premises, the immaterial cultural heritage of the Balkan people also has the characteristic of a shared heritage, be it mythical, folkloric, historical, religious or artistic. Such an attitude has no intention to negate the separate specifics of the different cultural corpuses. It only points to another, not so obvious side of the historical truth, which, even as such, invisible or partly hidden, should be taken into consideration in the contemporary system of cultural and civilizational values.

\section{Instead of an Epilogue}

\subsection{Balkan Interpretative Strategies}

The balance between the male and the female principle in the Balkans is "work in progress". The state of empathy is something in between reality and illusion, cohabitation and shadows of the past. Throughout history, the Balkans have been a "cradle of civilizations" longer than a "powder keg". The colonial and postcolonial Balkan cultural hegemonism leads not to integration but to its fragmentation. The methods of balkanisation are used to establish radical polycentrism and the process of balkanisation appears as a new actualisation of the archetypical imperial strategy known as 'divide et impera' (Kulavkova, 2006). Several colonial interpretative strategies remain dominant on the Balkans:

- An adaptive strategy, which goes hand in hand with the exclusivist strategy: it is a method of adopting the history, culture, tradition and territory of the Other/the neighbour, thereby denying its right of identity and the right to claim the same history;

- A strategy of systematic denial (of identity) of the Other and its right to have its own history, territory, country, church;

- A competitive strategy, based on the myths of autochthony and domicile status of the Balkan peoples, taken as an excuse to legitimise expansionist politics and usurp the right of the Other over a territory, history and culture; 
- A strategy of conversions, which includes the politics of religious, ethnic and linguistic conversion, with the aim of revising history, followed by a revision of the current state structures and borders. No distinction is made between the history of the territory and the history of the peoples, which causes further confusion, as the Balkan territories have often been divided, the borders between countries have been revised, and the peoples have been subjected to religious, ethnic and linguistic conversions. Such a history of the Balkans explains the phenomena of changing identities (forceful, under pressure, voluntary), as well as fluid and liminal ones.

\subsection{Cultural Hegemony or Culture of Empathy?}

Hegemonistic cultural strategies aim to exert dominance of the national states over neighbouring state(s) that converted into multi-ethnic states with multi-ethnic political regimes (Bosnia and Herzegovina, Macedonia). The current Balkan hegemonism contains elements of all the previously mentioned strategies: adoption, negation, competitive autochthony and conversion. All of this leads to an improper and incomplete recognition of the neighbouring Balkan cultural and historical identities in time and space. These post-postcolonial interpretative strategies, inspired by the obsessive "narcissism of minor differences" (Freud, 1917), is missing empathy towards the Other and a sense of reality. The shared places of memory (mythical, folkloric, historical or cultural) are a good reason for creating a societal ambience of empathy and a scientific consensus on the transnational aspects of the cultural heritage of the contemporary Balkan nations.

\section{References:}

1. Akinari, Ueda. (1966) Priče kiše i meseca, pp. 82-93. Beograd: Nolit. [ $1^{\text {st }}$ ed. 1776, Ugetsu Monogatari or Tales on Moonlight and Rain]

2. Aristotle. Rhetoric. (2002) [Macedonian transl. by Vesna Tomovska, Skopje: Makedonska kniga] http://classics.mit.edu/Aristotle/rhetoric.1.i.html

3. Bunson, Matthew. (1993) The Vampire Encyclopedia, New York: Gramercy Books, pp. 57-58.

4. Dinekov, Peter. (2009) Bulgarska narodna balada, V sveta na bulgarskata narodna balada" SbNU, Bulgarian Philology / Blgarska filologia, 60 , http://bgphilology2008.blogspot.com/2009/06/20090601-13_01.html

5. Durand, Gilbert. (1969) Les structures mystiques de l'imaginaire, In : Les structures anthropologiques de l'imaginaire (pp. 307-320). Paris: Dunod.

6. Evangel by John 11: 1-45. Bible. 
7. Freud, Sigmund. (1917) The Taboo of Virginity. (Freud's lecture given to the Vienna Psychoanalytical Society on December 12, 1917). http://users.clas.ufl.edu/burt/deathsentences/freudtaboo.pdf

8. Haraldsson, Erlendur. (2006) Popular psychology, belief in life after death and reincarnation in the Nordic countries, Western and Eastern Europe. In: Nordic Psychology, 58 (2), pp. 171-180. Available: http://www3.hi.is/ erlendur/english/Nordic_Psychology_erlhar06.pdf

9. Kulavkova, Katica. (2006) "Balkanski model na svet". In: Balkanska slika na svet, pp. 15-50 (ed. by K. Kulavkova). Skopje: MASA.

10. Kulavkova, Katica. (2009) From a Black God to a Black Arab: different mythical and historical actualizations of the universal matrix of Black, in: The Black Arab as a Figure of Memory, Interpretations Vol. 3 (ed. by K. Kulavkova), pp. 21-49. Skopje: MANU.

11. Maalouf, Amin. (2003) In the Name of Identity: Violence and the Need to Belong. New York: Penguin Books. Available: https://theoldnewway.files.wordpress.com/2015/12/maalouf-amin-inthe-name-of-identity-violence-and-the-need-to-belong-2003.pdf

12. Papucakis, Hristos. (Ed.) (2008) Haemus: antologija balkanske poezije. Beograd: Serbian PEN. Serbian edition and translation $\left[1^{\text {st }}\right.$. ed. Athens, Anti, 2005].

13. Peeva, Adela. (2003) Whose Is This Song? (Chia e tazi pesen?). https://hbogo.me/filmovi/cija-je-ovo-pesma https://www.imdb.com/title/tt0387926/

14. Penušliski, Kiril. (1983) Makedonski narodni baladi. Skopje: Makedonska kniga.

15. Petrić, Vladimir. (1966) Introduction to the Ueda Akinari's book Priče kiše i meseca, pp. 21-27. Beograd: Nolit.

16. Plato. (2004) Book 10, Republic. Indianapolis/Cambridge: Hackett Publishing. Company Inc.

https://123philosophy.files.wordpress.com/2018/12/PlatoRepublic.pdf

17. Puchner, Walter. (2016) Three Greek Folk Ballads in their Balkan Context. In: Modern Greek studies Online, 2, pp. 67-90. https://www.academia.edu/28901900/Walter_Puchner_Three_Greek_ Folk_Ballads_in_their_Balkan_Context_2016.pdf

18. Searle, John. (2003) From Speech Acts to Social Reality. ResearchGate.

http://researchgate.net/publication/238744002_John_Searle_From_S peech_Acts_to_Social_Reality/link/0c96052e01c387efbb000000/do wnload

19. Shishmanov, Ivan. (2009) Pesenta za mrtvia brat v poeziata na balkanskite narodi $\left[1^{\text {st }}\right.$. ed. SbNU 1896]. Bulgarian Philology (2008- 
November 2021 edition Vol.17, No.39

2009). http://bgphilology2008.blogspot.mk/2009/06/2009060113_01.html

20. Verković, Stefan. (1985) Makedonski narodni umotvorbi, Vol. 2 \& 3, pp. 59-65, ed. by K. Penušliski. Skopje: Makedonska kniga. 